\title{
Analysis of food advertisements on cable television directed to children based on the food guide for the Brazilian population and current legislation
}

\author{
Análise das propagandas de alimentos veiculadas \\ em canais de televisão fechada direcionada ao \\ público infantil segundo o guia alimentar \\ para a população brasileira e legislação vigente
}

Soraya da Rocha BRITTO

Renata Furlan VIEBIG 1,2

Juliana Masami MORIMOTO'

\section{A B S T R A C T}

\section{Objective}

This study examined food product advertisements directed to children and aired on closed television channels in Brazil, according to the types of foods and beverages advertised and the advertising content.

\section{Methods}

A descriptive study was conducted on the adequacy of food commercials directed to children and aired by six pay-television broadcasters according to two parameters: "The Food Guide for the Brazilian Population, 2014", and the National Council on Children's and Adolescents' Rights Resolution n ${ }^{\circ} 163$ of 2014 about food advertising. The advertisements were recorded in July 2015, at different times and days of the week.

\section{Results}

One hundred and sixty-two hours were recorded, registering 3,468 commercials: 1,850 were related to internal programming and 1,618 advertised toys $(22.15 \%)$, food and beverages $(5.61 \%)$, applications for electronic

\footnotetext{
1 Centro Universitário São Camilo, Programa de Pós-Graduação Stricto Sensu em Nutrição do Nascimento à Adolescência. R. Dr. Raul Pompéia, 144, Pompeia, 05025-010, São Paulo, SP, Brasil. Correspondência para/Correspondence to: RF VIEBIG. E-mail: $<$ refurlan@gmail.com>

2 Universidade Presbiteriana Mackenzie, Centro de Ciências Biológicas e da Saúde, Curso de Nutrição. São Paulo, SP, Brasil. Article based on the master's thesis of SR BRITTO, entitled "Análise das propagandas de alimentos veiculadas em canais de televisão fechada direcionada ao público infantil segundo o Guia Alimentar para a população brasileira e legislação vigente". Centro Universitário São Camilo; 2015.
} 
devices (5.58\%), and entertainment/events (5.56\%). The Fisher exact test showed fewer number of food commercials compared to other types of commercials $(p<0.001)$. The main food items advertised by all television stations were ultraprocessed foods and no advertisements of fresh food were observed $(p<0.001)$. Most of the food commercials (64.30\%) used children's language and characters; $43.00 \%$ used songs in children's voices, and $21.40 \%$ linked gift distribution to food.

\section{Conclusion}

The number of food commercials observed was lower than in previous national studies. However, the advertisements did not follow current legislation, indicating the abuse of marketing communication to children. More effective public policies and the respect and enforcement of legislation on child advertising could protect children from high consumption of ultraprocessed foods.

Keywords: Child. Food publicity. Pediatric obesity. Television.

\section{R E S U M O}

\section{Objetivo}

O presente estudo analisou propagandas de produtos alimentícios voltados ao público infantil veiculadas em emissoras de televisão fechada do Brasil, de acordo com os tipos de alimentos e conteúdo publicitário.

\section{Métodos}

Estudo descritivo sobre a adequação de propagandas de alimentos veiculadas em seis emissoras de televisão por assinatura e direcionadas a crianças segundo dois parâmetros: "Guia Alimentar para a População Brasileira, 2014" e Resolução no 163 de 2014 do Conselho Nacional dos Direitos da Criança e do Adolescente, sobre publicidade de alimentos. A gravação das propagandas foi realizada em julho de 2015, em diferentes horários e dias da semana.

\section{Resultados}

Foram registrados 3468 comerciais em 162 horas de gravação, sendo 1850 referentes à programação interna e 1618 a brinquedos (22,15\%), alimentos e bebidas (5,61\%), aplicativos para aparelhos eletrônicos (5,58\%) e entretenimento/eventos (5,56\%). O teste exato de Fisher mostrou menor número de comerciais de alimentos em comparação aos demais tipos de propaganda $(p<0,001)$. Os itens alimentares mais veiculados em todas as emissoras foram os alimentos ultraprocessados, com nenhuma inserção de comerciais de alimentos in natura $(p<0,001)$. Dos comerciais de alimentos, $64,30 \%$ apresentaram linguagem infantil/personagens, 43,00\% tinham músicas com vozes infantis e $21,40 \%$ vincularam a distribuição de brindes ao alimento.

\section{Conclusão}

O número de propagandas de alimentos observado foi menor do que o encontrado em estudos nacionais anteriores. Entretanto, os comerciais não estavam em conformidade com a legislação vigente, indicando abusividade de comunicação mercadológica à criança. Políticas públicas mais eficazes, bem como o respeito e cumprimento da legislação sobre publicidade infantil, poderiam proteger as crianças do elevado consumo de alimentos ultraprocessados.

Palavras-chave: Criança. Publicidade de alimentos. Obesidade pediátrica. Televisão.

\section{INTRODUCTION}

The eating habits of the Brazilian population have been changing in recent decades due primarily to changes in their daily lives and the labor market. These changes have resulted from multiple factors that distinguish modern life, such as urbanization; changes in the relationship between time and space; growth of industrialization; multiple roles attributed to women, who continue to play a central role in families' health and feeding; marketing; and others ${ }^{1}$.

Food consumption is determined by individuals' food choices and constitutes a complex process involving the interaction of biological, sociocultural, and psychological factors ${ }^{2}$. Studies show that children's eating habits are formed, first and foremost, by the influence of the family on 
which the child depends and, secondly, by other psychosocial and cultural interactions ${ }^{3}$.

In addition to the formation of eating habits during childhood, these days a push to consume foods in excessive quantities and of inferior quality is observed, with marketing, media, and the food industry encouraging the overconsumption of products that are high in sugars, sodium, and fats and poor in fiber and micronutrients ${ }^{4}$. There is evidence that these poor nutritional habits, encouraged by the media, carry over from childhood into adolescence and adult life, eventually leading to higher incidence of diabetes, high blood pressure, obesity, and cardiovascular disease $\mathrm{f}^{5}$. Because it plays such an important role in Brazilian family life, television can be used to broadcast important messages that promote health and prevent illness; at the same time, excessive exposure to television seems to be an indicator for heightened health risks ${ }^{6}$.

Childhood obesity is worrisome because, in addition to being a predisposing factor for serious associated illnesses, it reflects the inadequate dietary habits of families and communities. Television is currently considered an active and influential companion in early childhood, given Brazilian children's prolonged periods of television viewing ${ }^{4}$.

This study aims to analyze food product advertisements aimed at children that are aired on six Brazilian cable television channels with regard to the types of foods advertised and the content of the advertisements.

\section{METHODS}

The data were obtained by recording television programming aimed at children on six cable television channels with the largest viewing public, designated as $A, B, C, D, E$, and F. All the advertisements broadcast during the data collection period were identified, inventoried, and analyzed.
The recording was carried out in the city of São Paulo from July 1 to July 27, 2015, during the Brazilian school vacation period. The recording periods were structured to include morning, afternoon, night, and weekend programming on each channel. There were four periods over the course of four days for each channel, totaling 24 consecutive days of recording. The advertisements studied were broadcast in the morning, afternoon, and evening periods, from 8:00 a.m. to 11:00 p.m. Twenty-seven hours of programming was recorded on each channel, totaling 162 hours of recorded programming on all the six channels. The periods chosen for recording were based on studies such as Santos et al. ${ }^{5}$ and were defined as (i) morningfrom 8:00 a.m. to 12:00 noon, (ii) afternoon-from 2:00 p.m. to 6:00 p.m., and (iii) evening-from 7 p.m. to 11:00 p.m.

Before the recording began, criteria were established to describe the frequency of the advertisements and categorize the advertised products. This was done in the same way that Pimenta et al. ${ }^{3}$ adapted Santos \& Batalha ${ }^{7}$ proposal using content analysis to identify the products and appeals made in television commercials. This study also adapted to current conditions by adding the following product categories to Pimenta et al. ${ }^{3}$ proposal: "applications for cell phones, tablets, and computers" and "language schools and teaching systems".

After the commercials were classified by type, the category "internal programming advertisements" was excluded, since they were not advertising outside products or services. The food commercials were classified according to the type of food or beverage being advertised. The frequency of commercials shown on weekdays and weekends was analyzed, but no attention was paid to whether the advertisements appeared in the morning, afternoon, or evening periods.

Next, the Fisher exact test was used to compare the proportion of food and drink commercials with the total number of commercials for other products and services on each channel studied. It was also used to determine whether the proportion of food and 
drink commercials to commercials for other products and services varied from weekdays to weekends for each channel. In the following stage, the foods and drinks were classified into four groups: natural foods, minimally processed foods, processed foods, and ultraprocessed foods ${ }^{8}$. Fisher's exact test was used to analyze the data, considering values of $p<0.05$ as significant.

Advertisements were analyzed to see whether they complied with the nine aspects of Resolution $n^{\circ} 163$ of 2014 of the Conselho Nacional dos Direitos da Criança e do Adolescente (CONANDA, National Council on Children's and Adolescents' Rights) with regard to abusive advertising practices and marketing to children with the intention of persuading them to consume any product or service, specifically with regard to food and drink $^{9}$ (Chart 1).

\section{RE S U L T S}

During the 162 hours of recording, 3,468 commercials were counted, with $52.3 \%$ $(n=1,850)$ of the advertisements on the six channels being internal programming
Chart 1. Aspects of Resolution $n^{\circ} 163$ of the National Council on Children's and Adolescents' Rights (CONANDA) on food advertising directed toward children.

\begin{tabular}{ll}
\hline & Aspects of CONANDA Resolution $n^{\circ} 163$ of 2014 \\
\hline I - Child like language, special efects and excessive colors \\
II - Sound tracks with children's tunes or sung by children \\
III - Images of children \\
IV - Personalities or celebrities who appeal to children \\
$V$ - Child personalities or presenters \\
VI - Cartoons or drawings \\
VII - Dolls or doll-like figures \\
VIII - Distribuition of prizes or collectibles that appeal to children \\
IX - Games or contests that appeal to children \\
\hline
\end{tabular}

advertisements that promoted other programs on the same channel. These advertisements were excluded from the analysis of commercials by outside advertisers. Of the 1,618 (47.7\%) remaining commercials on all channels, the majority $(22.15 \%)$ promoted toys. Food and drink advertisements accounted for 190 of the commercials ( $5.61 \%$ of total commercials), with similar percentages observed for applications for electronic devices (5.59\%) and entertainment (5.57\%; Figure 1).

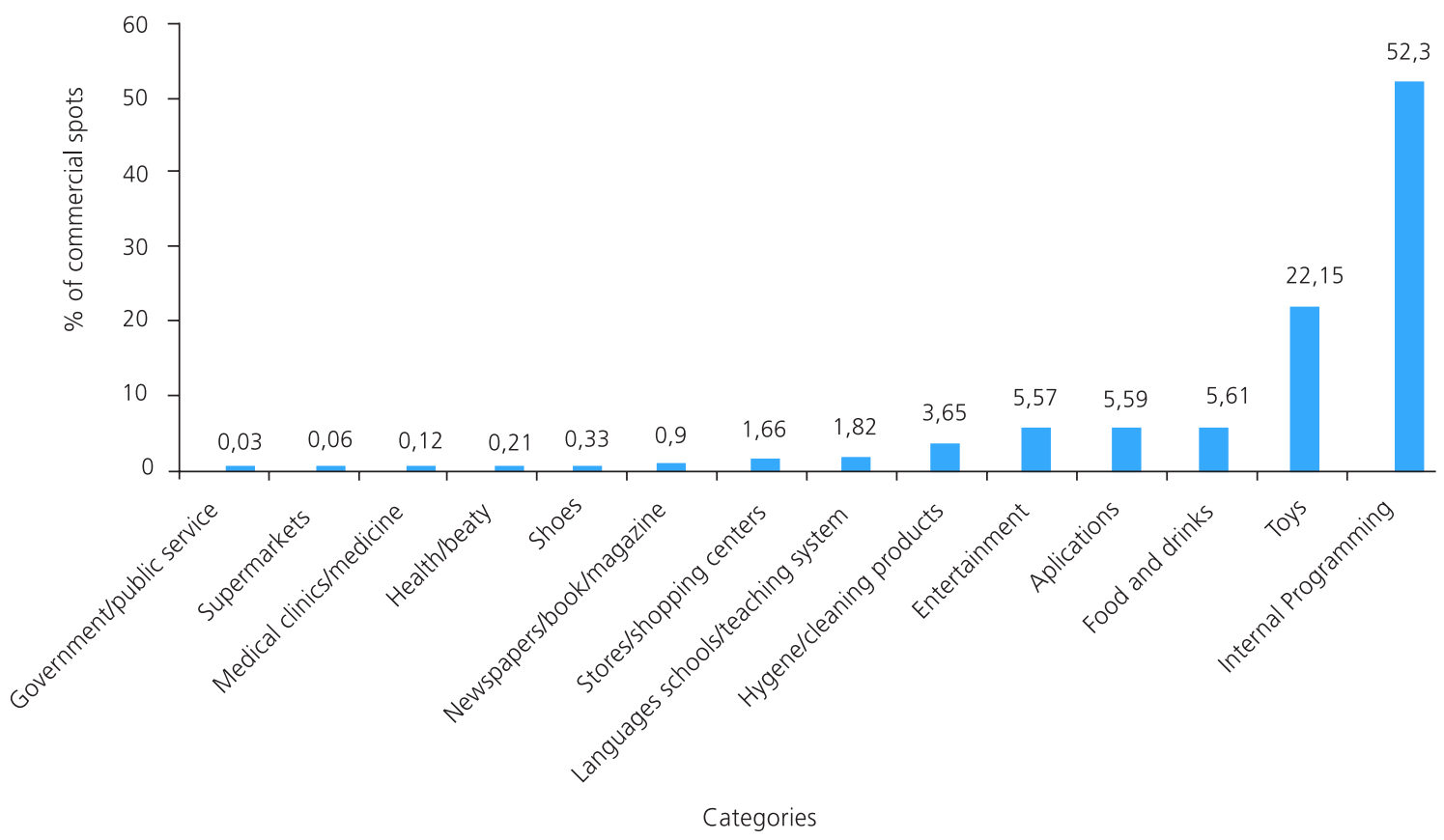

Figure 1. Percentage distribution by category for commercials identified in the sample of recorded programs $(n=3,468)$. 
It was concluded that there were smaller number of food and drink commercials compared to other types of advertising on all of the channels studied, and that the difference was statistically significant $(p<0.001)$. A statistically significant difference $(p<0.05)$ was observed for channels $D$, $E$, and $F$ in which fewer commercials for food and drinks aired on weekends (Table 1).

Of the 1,618 remaining commercials aired on all channels, the category of food and drinks accounted for 190 commercials $(5.6 \%$ of the total). Table 2 shows the categorization of the most advertised food items on all channels by percentage and in absolute numbers. Candy and packaged snacks were advertised only on channel E, with each accounting for $5.0 \%$ of the advertisements on that channel. Three channels carried advertisements for fast food restaurants, with fast food commercials making up almost a third of the food item advertisements on channel F. Only one channel (channel C) carried advertisements for processed meats in their programming; this was also the only channel that carried advertisements for whole grain rice, which is considered a less processed and healthier food.

Figure 2 shows the distribution of advertised food products by their degree of processing, following the definitions proposed in the "Food Nutrition Guide for the Brazilian Population, 2014". The food items most advertised on all channels were ultraprocessed foods, and no commercials for natural foods were observed $(p<0.001)$.

With regard to whether the food and drink commercials complied with the CONANDA Resolution $n^{\circ} 163$ of 2014, it was found that the items "whole grain rice", "infant formula", "processed meats", and "milk" were in complete compliance with the applicable laws as these advertisements were directed at adult viewers.

Commercials for "fast food", "candy", "powdered soft drinks", "soy-based juice", "breakfast cereal", and "snacks" were in partial compliance with the applicable laws. Commercials

Table 1. Proportion of food/drink advertisements to advertisements for other products/services, in absolute numbers with respect to week days and weekends $(n=1,618)$.

\begin{tabular}{|c|c|c|c|c|c|c|}
\hline \multirow{2}{*}{ Channel } & \multirow{2}{*}{ Type } & \multicolumn{2}{|c|}{ Week days } & \multicolumn{2}{|c|}{ Weekends } & \multirow{2}{*}{ Value of $p^{*}$} \\
\hline & & $n$ & $\%$ & $\mathrm{n}$ & $\%$ & \\
\hline \multirow[t]{3}{*}{ A } & Food and drinks & 1 & 3.3 & 5 & 10.4 & 0.397 \\
\hline & Other products and services & 29 & 96.7 & 43 & 89.6 & \\
\hline & Total & 30 & 100.0 & 48 & 100.0 & \\
\hline \multirow[t]{3}{*}{$B^{* *}$} & Food and drinks & - & & - & & \\
\hline & Other products and services & 5 & 100.0 & 9 & 100.0 & - \\
\hline & Total & 5 & 100.0 & 9 & 100.0 & \\
\hline \multirow[t]{3}{*}{ C } & Food and drinks & 13 & 11.1 & 11 & 13.1 & 0.667 \\
\hline & Other products and services & 104 & 88.9 & 73 & 86.9 & \\
\hline & Total & 117 & 100.0 & 84 & 100.0 & \\
\hline \multirow[t]{3}{*}{ D } & Food and drinks & 37 & 15.0 & 27 & 9.2 & 0.045 \\
\hline & Other products and services & 209 & 85.0 & 267 & 89.8 & \\
\hline & Total & 246 & 100.0 & 294 & 100 & \\
\hline \multirow[t]{3}{*}{ E } & Food and drinks & 33 & 25.6 & 27 & 13.7 & 0.008 \\
\hline & Other products and services & 96 & 74.4 & 170 & 86.3 & \\
\hline & Total & 129 & 100.0 & 197 & 100.0 & \\
\hline \multirow[t]{3}{*}{$\mathrm{F}$} & Food and drinks & 29 & 13.7 & 7 & 2.8 & $<0.001$ \\
\hline & Other products and services & 183 & 88.3 & 240 & 97.2 & \\
\hline & Total & 212 & 100.0 & 247 & 100.0 & \\
\hline
\end{tabular}

Note: "Fisher exact test; ${ }^{* *}$ The Fisher exact test was not applied to channel B since it did not broadcast any food or drink commercials. 
Table 2. Percentage distribution and absolute numbers of food items advertised in commercials on each channel, according to the product $(n=190)$.

\begin{tabular}{|c|c|c|c|c|c|c|c|c|c|c|}
\hline \multirow{2}{*}{ Food Items } & \multicolumn{2}{|c|}{ Channel A } & \multicolumn{2}{|c|}{ Channel C } & \multicolumn{2}{|c|}{ Channel D } & \multicolumn{2}{|c|}{ Channel E } & \multicolumn{2}{|c|}{ Channel F } \\
\hline & $n$ & $(\%)$ & $\mathrm{n}$ & $(\%)$ & $n$ & $(\%)$ & $n$ & $(\%)$ & $\mathrm{n}$ & $(\%)$ \\
\hline Chocolate (powder and liquid) & - & - & - & - & 14 & 21.88 & 5 & 8.33 & 7 & 19.44 \\
\hline Whole grain rice & - & - & 5 & 20.83 & - & - & - & - & - & - \\
\hline Candy & - & - & - & - & - & - & 3 & 5.00 & - & - \\
\hline Cereal bar & - & - & - & - & - & - & - & - & 2 & 5.56 \\
\hline Breakfast cereal & - & - & 2 & 8.33 & - & - & - & - & - & - \\
\hline Fast food & - & - & - & - & 4 & 6.25 & 1 & 1.67 & 11 & 30.56 \\
\hline Infant formula & 5 & 83.33 & - & - & 5 & 7.81 & - & - & 2 & 5.56 \\
\hline Yogurt/fermented dairy drink & - & - & 1 & 4.17 & 20 & 31.25 & 26 & 43.33 & 3 & 8.33 \\
\hline Milk & - & - & - & - & 21 & 32.81 & & & - & - \\
\hline Processed meat & - & - & 9 & 37.50 & - & - & - & - & - & - \\
\hline Powdered soft drink & - & - & - & - & - & - & - & - & 10 & 27.78 \\
\hline Snacks & - & - & - & - & - & - & 3 & 5.00 & - & - \\
\hline Petit Swiss creamy cheese & 1 & 16.67 & 7 & 29.17 & - & - & - & & - & - \\
\hline Soy-based juice & - & - & - & - & - & - & 22 & 36.67 & 1 & 2.78 \\
\hline Total & 0 & 100 & 0 & 100 & 0 & 100 & 0 & 100 & 0 & 100 \\
\hline
\end{tabular}

Note: Channel B aired no food advertisements.

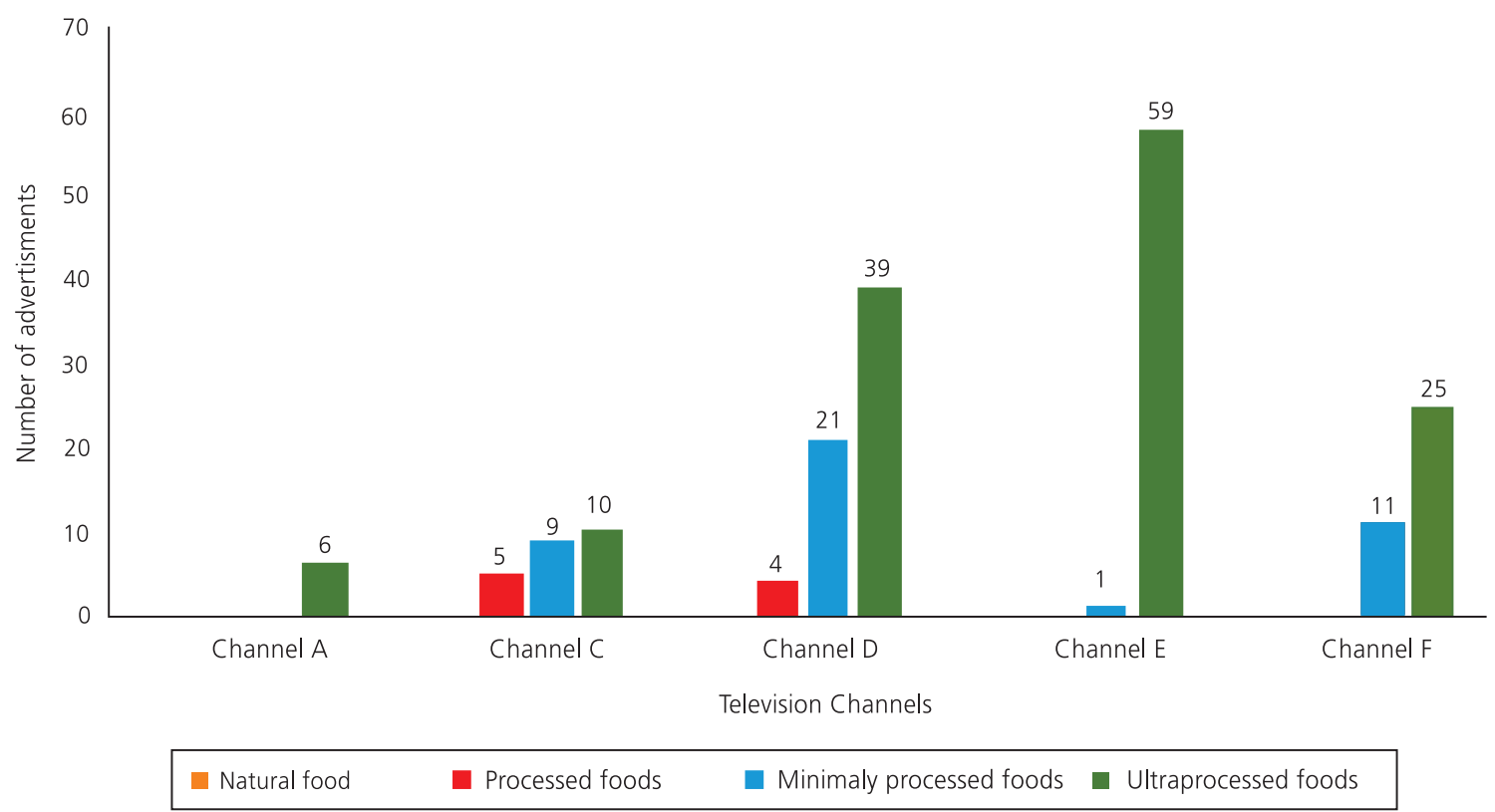

Figure 2. Categorization of advertised foods and drinks according to the "Food Nutrition Guide for the Brazilian Population", by channel. Channel B aired no food advertisements.

for "cereal bars", "chocolate", "Petit Swiss creamy cheese snack", and "yogurt/fermented dairy drinks" were in least compliance with the laws; the last two categories were the most advertised food items overall on the channels during the period recorded. It is worth noting that of all the food and drink advertisements aired, "yogurt/fermented dairy drinks" complied with only one criterion in the applicable laws ("absence of celebrities or personalities who appeal to child 
viewers") and infringed all other guidelines proposed in the resolution. In addition, it was observed that of the 14 food and drink commercials broadcast on cable television, nine (64.3\%) employed childlike language and characters, six (43.0\%) contained children's tunes or songs sung by children, and three (21.4\%) linked the food items to prizes.

\section{DISCUSSION}

Commercials for food and drinks came in second place among all the products advertised on the channels studied, surpassed by only toy advertisements. The most advertised foods were ultraprocessed foods, which, in general, are high in sugars, fats, and sodium and can be related to the rising prevalence of obesity and chronic diseases among the population of Brazilian children. These foods and drinks also contain preservatives, dyes, and artificial flavors that are considered unsuitable for children's nutrition.

The predominance of ultraprocessed foods in advertisements can be considered contrary to the recommendations published in the most recent 2014 Food Nutrition Guide for the Brazilian Population ${ }^{8}$. This guide advises the public to reduce consumption of these products to the possible minimum and recommends that a variety of natural foods or minimally processed foods, predominantly vegetables, should form the basis of the diet of the country's families ${ }^{8}$.

This study found that candy and packaged snacks were advertised on only one channel, each making up $5.0 \%$ of the food commercials. This can be considered progress in terms of regulating food advertising directed at children, especially as Halpern's 2003 analysis of commercials on broadcast television found that snacks accounted for the largest category of food advertisements $(25.9 \%)^{10}$. When Halpern analyzed the advertised products with regard to the food pyramid adapted by Phillipi et al. ${ }^{11}$, she found foods containing fats, oils, and sugars present in most of the advertisements.
Similarly, more recent studies, such as the 2011 study by Pimenta et al. ${ }^{3}$, showed a higher percentage of candy advertisements on broadcast television channels and that most of the advertised products were high in sugars (56.0\%). Similarly, in their 2012 study, Santos et al. ${ }^{5}$ found that $85.0 \%$ of the food advertisements on broadcast television were for products high in sugars, oils, and fats. Along the same lines, Costa et al. ${ }^{12}$ study of broadcast television commercials found a predominance of products belonging to sugar groups (48.1\%) and oils, fats, and oily seeds/ nuts $(29.1 \%)$.

Among all the 190 food and drink commercials observed in the present study, only the item "whole grain rice", which represented one-fifth of the advertisements on channel C, cited some nutritional characteristics of the product. None of the other commercials cited nutritional characteristics of the advertised food products, implying that the food's nutritional value is not considered a relevant requirement when it is purchased. Of the 38 commercials analyzed by Halpern, only five cited the product's nutritional characteristics $^{10}$.

The food and drink commercials analyzed in this study, which were broadcast in 2015, should have followed the criteria for advertising to children proposed by the CONANDA resolution ${ }^{9}$ with respect to the advertisements' content. However, it was found that some advertisements did not conform to the resolution's criteria, with the most common infringement being the use of child characters and childlike language. In addition, it was found that yogurt, a food item considered "healthy" for children, was the product that most frequently infringed the child marketing guidelines in its commercials.

These results confirm the information published by prominent research institutes, showing that advertising directed at children through marketing, creative messages and media makes use of ongoing research to take advantage of children's vulnerability in order to benefit product sales ${ }^{13}$. 
A World Health Organization study that examined the nature of marketing campaigns in multiple countries ${ }^{14}$ found that marketing campaigns for soft drinks and foods seek to establish emotional bonds with children, create the idea of "fun and happiness" to promote brand loyalty, and stimulate repeated purchases by promoting collections. The study also found that their marketing included sponsoring sports, musical events, and children's programs, and that marketing through schools is a key tactic adopted by soft drink manufacturers in Latin America.

The present study found a significantly lower number of food commercials in comparison to other types of commercials. Studies from previous years found a larger number of food and drink commercials than were observed in this study. For example, Halpern ${ }^{10}$ study found four times more food commercials in relation to the total number of commercials that this study found. A larger number of food advertisements were also observed by Pimenta et al. ${ }^{3}$ in their study of two broadcast channels and by Costa et al. ${ }^{12}$ in their study of three broadcast channels.

This reduction in the number of food commercials observed in the present study may be a reflection and result of recent efforts by businesses and industries to meet the requirements of the CONANDA resolution. Even if the resolution's requirements are not strictly observed by advertisers in all cases, the publication of these norms may have resulted in fewer food product advertisements being aired. Thus, this resolution may be considered the first definitive step toward regulating food advertising in Brazil. In addition, it may have played a fundamental and positive role in reflecting on the abusive effects of food advertisements, especially advertisements for unhealthy foods, on child viewers.

Another victory was recently observed in this regard when, on March 2, 2016, the Associação Brasileira da Indústrias de Refrigerantes e Bebidas não Alcoólicas (ABIR, Brazilian Association of Soft Drink and Non-Alcoholic Drink Manufacturers) advised its members to stop creating advertising campaigns aimed at children under the age of 12 . ABIR said that its members, who account for $85 \%$ of the national production of soft drinks, juices, teas, energy drinks, and bottled water, have already significantly reduced their advertisements and promotional activities aimed at children over the recent years. They also said that this new initiative is in line with the international commitments they have already made $^{15}$.

As far as is known, this study is the first to evaluate food and drink commercials aired on cable television in Brazil. However, one shortcoming of the present study is worth noting: It lacks a comparison between the food and drink commercials aired on the cable television channels studied and those that aired on broadcast television channels during the same period. Although the results of recent market research showed a significant reduction in children's programming and advertising aimed at children and adolescents on broadcast television, such a comparison could show interesting results. In addition, the present study did not perform content analysis on the advertising messages, nor did it evaluate the amount of fat, sugar, sodium, and other nutrients in the advertised foods.

\section{CONCLUSION}

Although there have been important changes in food advertising aimed at children in Brazil, the commercials aired on the channels studied did not conform to current national law and recommendations, especially with regard to abusive practices in marketing aimed at children.

This study showed a marked reduction in the number of food advertisements aired in comparison with previous studies, even though the previous studies looked at broadcast television. However, the present study also showed that ultraprocessed foods were the foods most frequently found in advertisements and that no commercials for natural foods were aired. 
The findings of this study underline the need to implement broader resolutions with regard to food advertising aimed at children and emphasize the urgency of enforcing the guidelines set out in the law. The food industry should also be encouraged and involved in the process to produce food and drinks that have more suitable nutritional content, especially when children are the intended consumers, in order to minimize the impact of a diet rich in ultraprocessed foods on childhood obesity and its consequences. At the same time, educational campaigns should be implemented to better inform Brazilian families and children about the nutritional value of foods, so that they can reduce the consumption of foods that raise the risk of children becoming overweight or obese.

\section{CONTRIBUTORS}

SR BRITTO and RF VIEBIG contributed to the study's conception and design, data collection, tabulation, data analysis, and discussion of the results, as well as to the writing, editing, and revising of the article. JM MORIMOTO collaborated on data analysis and discussion of the results.

\section{REFERENCES}

1. Henriques P, Sally EO, Burlandy L, Beiler RM. Regulamentação da propaganda de alimentos infantis como estratégia para a promoção da saúde. Cien Saúde Colet. 2012; 17(2):481-90.

2. Alvarenga $M$, Figueiredo $M$, Timerman $F$, Antonaccio C. Nutrição comportamental. Barueri: Manole; 2015.

3. Pimenta DV, Masson DF, Bueno MP. Análise das propagandas de alimentos veiculadas na televisão durante a programação voltada ao público infantil. J Health Sci Inst. 2011; 29(1):52-5.

4. Santos AM, Scherer PT. Mídia e obesidade infantil: uma discussão sobre o peso das propagandas. Rev Famecos. 2014; 21(1):208-23.

5. Santos CC, Stuchi RAG, Sena CA, Pinto NAVD. A influência da televisão nos hábitos, costumes e comportamento alimentar. Cogitare Enferm. 2012; 17(1):65-71.
6. Mattos MC, Nascimento PCBD, Almeida SS, Costa TMB. Influência de propagandas de alimentos nas escolhas alimentares de crianças e adolescentes. Psic: Teor e Prat. 2010; 12(3):34-51.

7. Santos SL, Batalha MO. A ética na propaganda de alimentos: uma análise a partir dos comerciais de televisão. In: Anais do $45^{\circ}$ Congresso da Sociedade Brasileira de Economia e Sociedade Rural. Londrina: Publisher; 2007.

8. Brasil. Ministério da Saúde. Secretaria de Atenção à Saúde. Departamento de Atenção Básica. Guia alimentar para a população Brasileira. Brasília: Ministério da Saúde; 2014.

9. Secretaria de Direitos Humanos. Conselho Nacional dos Direitos da Criança e do Adolescente (CONANDA). Resolução n 163, de 13 de março de 2014: dispõe sobre a abusividade do direcionamento de publicidade e de comunicação mercadológica à criança e ao adolescente. Diário Oficial da União. 2014; 4 abril, p.4, Seção 1, n.65.

10. Halpern G. Comerciais veiculados em programação infanto-juvenil de canais abertos de TV e sua relação com a escolha de alimentos em amostra de escolares: um estudo amostral dos comerciais veiculados em canais abertos de televisão, e sua influência numa pequena amostra de escolares do município de São Paulo. São Paulo: Universidade Federal de São Paulo; 2003.

11. Philippi ST, Latterza AR, Cruz ATR, Ribeiro LC. Pirâmide alimentar adaptada: guia para escolha dos alimentos. Rev de Nutr. 1999; 12(1):65-80. http:// dx.doi.org/10.1590/S1415-52731999000100006

12. Costa SMM, Horta PM, Santos LC. Análise dos alimentos anunciados durante a programação infantil em emissoras de canal aberto no Brasil. Rev Bras Epidemiol. 2013; 16(4):976-83.

13. Criança e Consumo, Instituto Alana. Por que a publicidade faz mal as crianças. 2009 [acesso 2015 nov 6]. Disponível em: http://criancaeconsumo. org.br/wp-content/uploads/2014/02/por-que-apublicidade-faz-mal-para-as-criancas.pdf

14. World Health Organization. Globalization, diets and noncommunicable diseases. Geneva: WHO Publications; 2002.

15. Associação Brasileira da Indústrias de Refrigerantes e Bebidas não Alcoólicas. A indústria brasileira de bebidas não alcoólicas e o marketing direcionado às crianças. Brasília: ABIR; 2015. [acesso 2016 mar 20]. Disponível em: http://abir.org.br/marketing_ criancas/ 
